University of South Florida

DIGITAL COMMONS

Digital Commons @ University of

@ UNIVERSITY OF SOUTH FLORIDA

South Florida

Marine Science Faculty Publications

College of Marine Science

1988

\title{
The Mathematician Paleoplate
}

J. Mammerickx

D. F. Naar

University of Hawaii, naar@usf.edu

R. L. Tyce

Follow this and additional works at: https://digitalcommons.usf.edu/msc_facpub

Part of the Life Sciences Commons

\section{Scholar Commons Citation}

Mammerickx, J.; Naar, D. F.; and Tyce, R. L., "The Mathematician Paleoplate" (1988). Marine Science Faculty Publications. 2242.

https://digitalcommons.usf.edu/msc_facpub/2242

This Article is brought to you for free and open access by the College of Marine Science at Digital Commons @ University of South Florida. It has been accepted for inclusion in Marine Science Faculty Publications by an authorized administrator of Digital Commons @ University of South Florida. For more information, please contact digitalcommons@usf.edu. 


\title{
The Mathematician Paleoplate
}

\author{
J. MAMMERICKX AND D. F. NAAR \\ Scripps Institution of Oceanography, La Jolla, California \\ R. L. TYCE \\ Graduate School of Oceanography, Kingston, Rhode Island
}

\begin{abstract}
The Pacific seafloor is littered with small fragments of lithosphere captured from adjacent plates by past plate boundary reorganizations. One of the clearest examples of such a reorganization is documented in the Mathematician Seamounts region, where a distinctive geomorphology and well-developed magnetic anomalies are present. This reorganization involved a short-lived microplate between the failing Mathematician Ridge and a new propagating spreading center: the East Pacific Rise. It produced a transfer of a fragment of lithosphere from the Farallon to the Pacific plate, and also created a number of landforms and magnetic patterns, within and on the margins of the captured fragment; these make up the Mathematician paleoplate. In many cases, two sides of a microplate are active spreading ridges. A microplate evolves into a paleoplate when dual spreading ceases and full spreading resumes at the prevailing spreading ridge. We define a paleoplate as the area of the seafloor, from the axis of a failed rift to the boundary of resumed, full spreading. It includes a fragment of captured lithosphere and the lithosphere slowly accreted to it during the period of dual spreading, prior to complete abandonment of the failed rift. The Mathematician paleoplate has the following boundaries and components from west to east: the axis of the Mathematician failed rift, the fragment of captured Farallon plate, a complex rift initiation site at the Moctezuma Trough, a zone of slow spreading, and an as yet ill-defined eastem boundary where dual spreading stopped and full spreading resumed. The northem boundary of the paleoplate is the Rivera fracture zone; its southeastem boundary a now-inactive transform fault, the West $\mathrm{O}^{\prime}$ Gorman fracture zone. In this case, as well as in other more poorly documented ones, relict landforms and magnetic patterns are carried on the aging lithosphere, away from the spreading ridge, recording a former geometry.
\end{abstract}

\section{INTRODUCTION}

The tectonic evolution of the eastern Pacific became more complex as the Pacific-Farallon spreading axis approached the active convergent margin bounding the west coast of the Americas (Figure 1). Eastern Pacific plate boundaries changed from a continuous spreading ridge and continuous trench geometry to a discontinuous spreading ridge and transform faults, separating from one another the smaller remaining pieces of what was the once large Farallon plate [Atwater, 1970; Menard, 1978; Klitgord and Mammerickx, 1982]. Small plates now dot the eastern edge of the Pacific basin; their boundaries continue to realign and readjust.

One of the possible consequences of plate boundary readjustments is the abandonment of spreading ridge segments. Sclater et al. [1971] were the first to observe them in their discussion of the elevation of ridges and their relation to the age of the underlying crust. These authors speculated correctly that the Mathematician seamounts, rather than being an isolated group of seamounts, were the remnants of an old spreading center which terminated some time in the past by jumping several hundred kilometers to the east and producing the present East Pacific Rise (EPR). Anderson and Sclater [1972] showed that the jumping of the ridge crest hundreds of kilometers away would be expected to produce a large topographic discontinuity and provided several examples. Herron [1972] and Handschumacher [1976] went

Copyright 1988 by the American Geophysical Union.

Paper number 6B6190.

0148-0227/88/006B-6190\$05.00 on to identify numerous other long-distance spreading center jumps along the length of the EPR. None of these authors discussed the mechanism by which long-distance spreading ridge jumps occurred. Since then, occurrences of abandoned spreading ridge segments have been abundantly reported in the literature [Lonsdale and Klitgord, 1978; Lowrie et al., 1979; Batiza and Chase, 1981].

Short-distance spreading axis jumps were documented from a different set of evidence: offsets in the EPR axial magnetic anomaly that were not observed in older flank anomalies [Rea, 1976]. Rea proposed two mechanisms for their formation: either asymmetric spreading or a discrete axial jump due to the deepening of an off-axis fault; by tapping into the underlying magma chamber, this lateral fault becomes the preferred axis of extrusion.

Hey's [1977a, 1979] careful analyses of magnetic data led him to propose a more likely mechanism for shortdistance spreading center jumps by demonstrating their relationship with propagating rifts. Hey and coworkers showed how the breakup of the Juan de Fuca plate produced a shift in the location of the poles of rotation and how the process of ridge reorientation was accomplished by propagation of new spreading ridges at the detriment of old ones, the net effect of which was to produce spreading ridge jumps tens of kilometers away [Hey, 1977a; Hey and Wilson, 1982]. Some of the topographic counterparts to the magnetic characteristics of propagating rifts were predicted by Hey et al. [1980] and observed by Searle et al. [1981], Mammerickx [1984], and Searle and Hey [1983].

A major spreading reorganization in the Mathematician region involving the existence of a short-lived microplate and an apparent long-distance spreading center jump was 


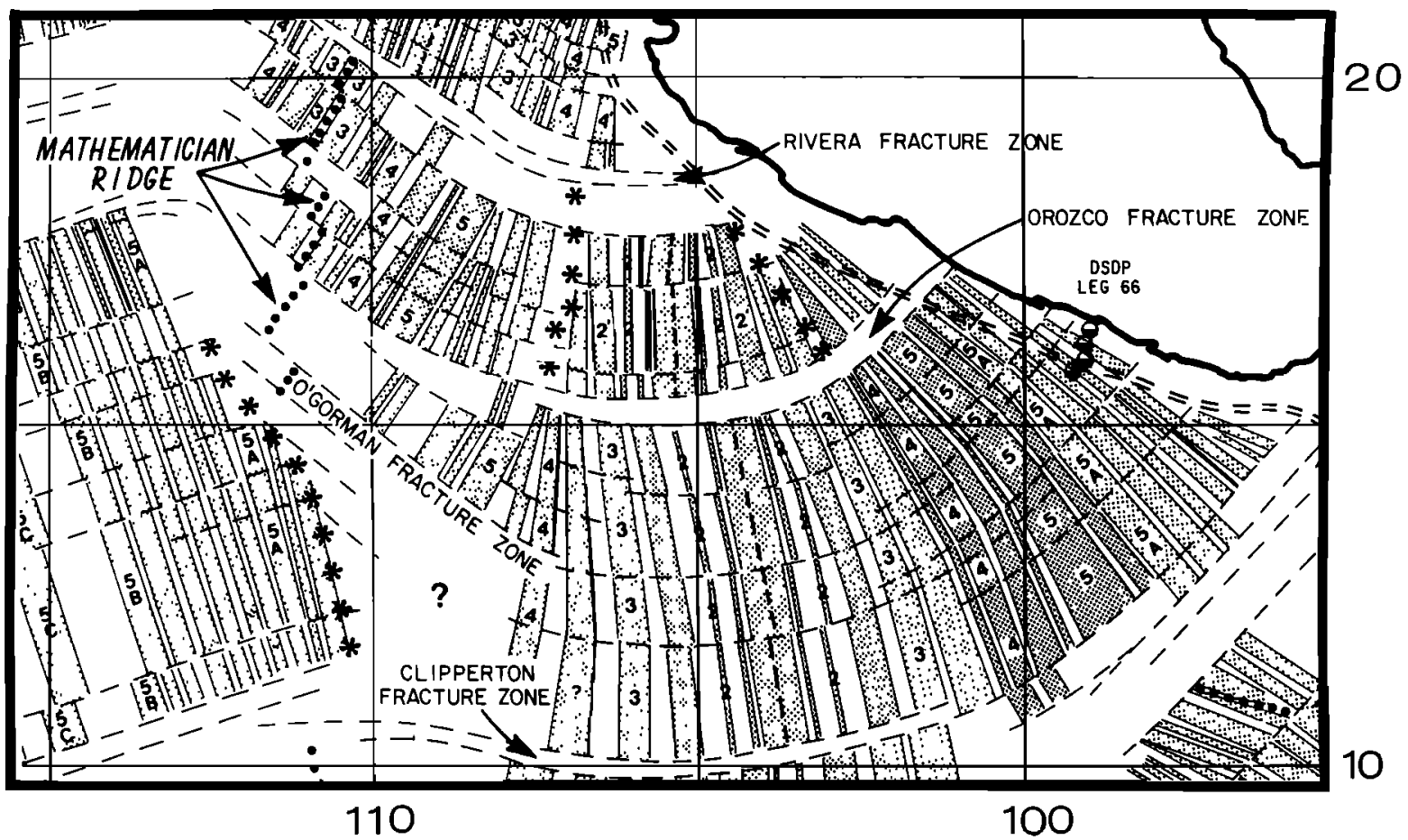

Fig. 1. Tectonic fabric for the eastem equatorial Pacific. The locations of the most important bathymetric features, such as fracture zones, trenches and aseismic ridges, and many of the seafloor spreading magnetic lineations are shown. Boundaries between oceanic crust generated at different spreading centers are indicated [from Klitgord and Mammerickx, 1982, Figure 2].

initially reported by Klitgord and Mammerickx [1982] and Mammerickx and Klitgord [1982]. A few million years ago, a microplate bound by two active spreading ridges (the Mathematician Ridge and the Moctezuma Troughs) existed in the northeast Pacific (Figures 1 and 2). At the conclusion of that episode of dual spreading, the western ridge was completely abandoned, and full spreading continued only at the remaining eastern ridge, which became the present-day EPR. A paleoplate was thus defined, that is, an area of the seafloor from a failed rift to the boundary where full spreading resumes; it includes a fragment of captured lithosphere and the lithosphere slowly accreted to it during the period of dual spreading, prior to the complete abandonment of the failed rift. Residual topographic and magnetic features in the seafloor on both sides of the EPR permanently record in the aging oceanic crust the telltale evidence of this episode of reorganization [Mammerickx, 1984; Mammerickx and Sandwell, 1986].

The residual features associated with the above mentioned plate reorganization (Figure 2) are from west to east: (1) the abandoned Mathematician spreading ridge with evidence of progressive failure, from south to north; (2) an area, between the Mathematician Ridge and the Moctezuma Trough, which is a captured fragment of Farallon plate; (3) the Moctezuma Trough, a complex group of parallel troughs which is marking the site where new spreading initiated in relatively old crust and where progressively younger anomalies disappear on the west flank of the EPR (one part of this complex trough is the inner pseudofault in Hey's [1977a] nomenclature; Mammerickx [1984]); (4) to the east of the Moctezuma Trough a triangular shaped area of rough topography; (5) a boundary where EPR spreading rates increased from the relatively slow dual rates to the faster full rate; (6) north and south bounding fracture zones with distinctive morphologic characteristics (the elements from 1 to 6 constitute what we call a paleoplate); and (7) east of the EPR, a mirror image set of some of these features ( 3 to 5) is observed: the rough-smooth boundary, an area of rough topography corresponding to relatively slower spreading rates and a conjugate rift initiation site (the Michoacan Troughs).

Our preliminary inventory of seafloor features suggests that this suite of morphological and magnetic features is a recurring pattern on the Pacific seafloor. We will propose a scenario for the formation and evolution of paleoplates as by-products of plate reorganizations.

We made detailed surveys of both the Moctezuma Troughs and the Mathematician Ridge with the Sea Beam system aboard R/V Washington during expedition Papatua, leg 3, in November and December 1985. Additional Sea Beam surveys and transit lines collected on R/V Atlantis and on R/V Washington Marathon 15 and Papatua 1 and 2 expeditions have been integrated with our data set.

Given the limited time devoted to the field investigation, we did not survey many critical areas: the interior of the area of transferred lithosphere, the northern boundary, and especially the southern part of the Mathematician Ridge and the western extension of the O'Gorman fracture zone. For that reason, critical elements of the paleoplate are still not thoroughly documented.

\section{The Mathematician Failed RIFT}

A 90-km segment of the Mathematician Ridge was surveyed with the Sea Beam system between $17^{\circ} \mathrm{N}$ and $18^{\circ} 30^{\prime} \mathrm{N}$ (Figure 3). The tracks are shown in Figure 4. Contours between the 17 crossings were interpolated. 


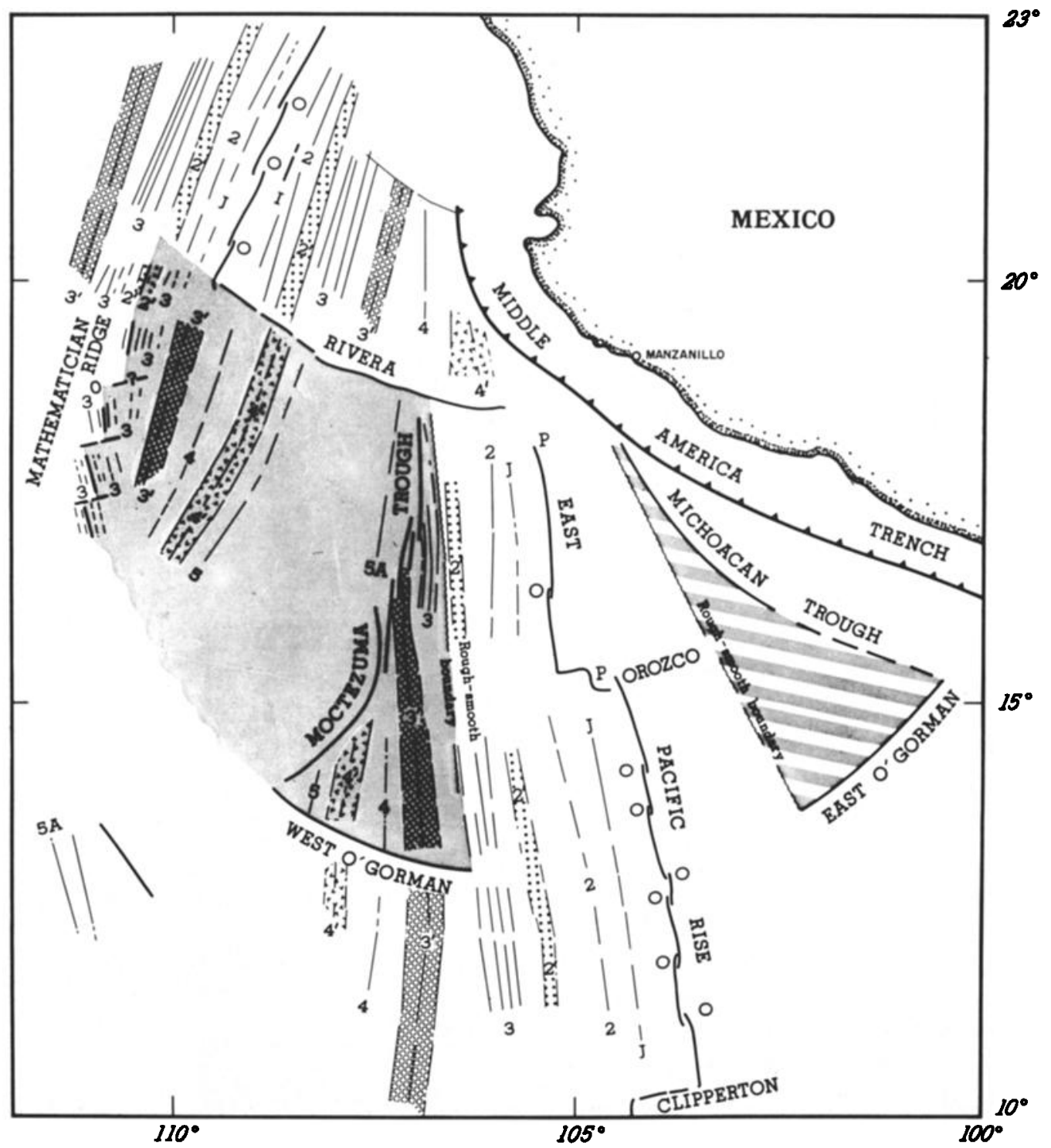

Fig. 2. The Mathematician paleoplate (shaded area) extends from the Mathematician Ridge to the rough-smooth boundary at $\sim 106^{\circ} \mathrm{W}$. The area of slow spreading between the Moctezuma Trough and the rough-smooth boundary has a mirror image equivalent east of the EPR. The arca of transferred lithosphere from the Mathematician Ridge to the Moctezuma Trough does noc. Circles are overtapping spreading centers [From Macdonald et al. 1984].

Three northwest trending ridge segments $\mathrm{N} 10^{\circ} \mathrm{W}$ are offset $18^{\circ} 50^{\prime} \mathrm{N}$ (Figures 2 and 3). The last eruption on the island by $10-\mathrm{km}$-long fracture zones. This northwest trend of the of San Benedicto, the top of another volcano, similarly loMathematician Ridge was not evident in the earlier analysis cated. $23 \mathrm{~km}$ farther north. occurred in 1952 [Richards, of surface ship data [Klitgord and Mammerickx, 1982]. The 1959]. Although spreading at this location ceased a few axis of the Mathematician Ridge is a $4000-\mathrm{m}$ trough, $500 \mathrm{~m}$ million years ago, a magma source has endured, and active wide on its flat floor, with scattered volcanoes 100 - to 200 - volcanism persists. South of $17^{\circ} \mathrm{N}$, a fracture zone offsets m high. This morphology [Tyce and Mammerickx, 1985] is the Mathematician Ridge $100 \mathrm{~km}$ to the west; we have not characteristic of the slow-spreading Mid-Atlantic Ridge determined the southern extension of the ridge.

[Ballard and van Andel, 1977]. The fracture zone valleys Throughout this paper we will use the convention for do not have the linear topography commonly seen at other magnetic anomaly identifications used by fIKlitgord and EPR ridge offsets [Macdonald et al., 1979] but rather are Mammerickx [1982]. Magnetic anomalies 3 and older are composed of northeast trending scarps with deep indenta- clearly identified in mirror image sets on the two segments tion and a general sawtooth pattern as seen at the Kruchatov of the failed Mathematician Ridge at $18^{\circ} \mathrm{N}$ (Figure 2). This fracture zone in the Atlantic [Searle and Laughton, 1977; interpretation places the failed ridge axis of symmetry west Searle, 1986].

of $111^{\circ} \mathrm{W}$ on the Vema 28 profile rather than east of it as in

A large volcano topped by the island of Socorro obstructs Klitgord and Mammerickx [1982] (Figures 4 and 5). At the northem end of the Mathematician median valley at $20^{\circ} \mathrm{N}$, surface ship data show that the age of extinction is 


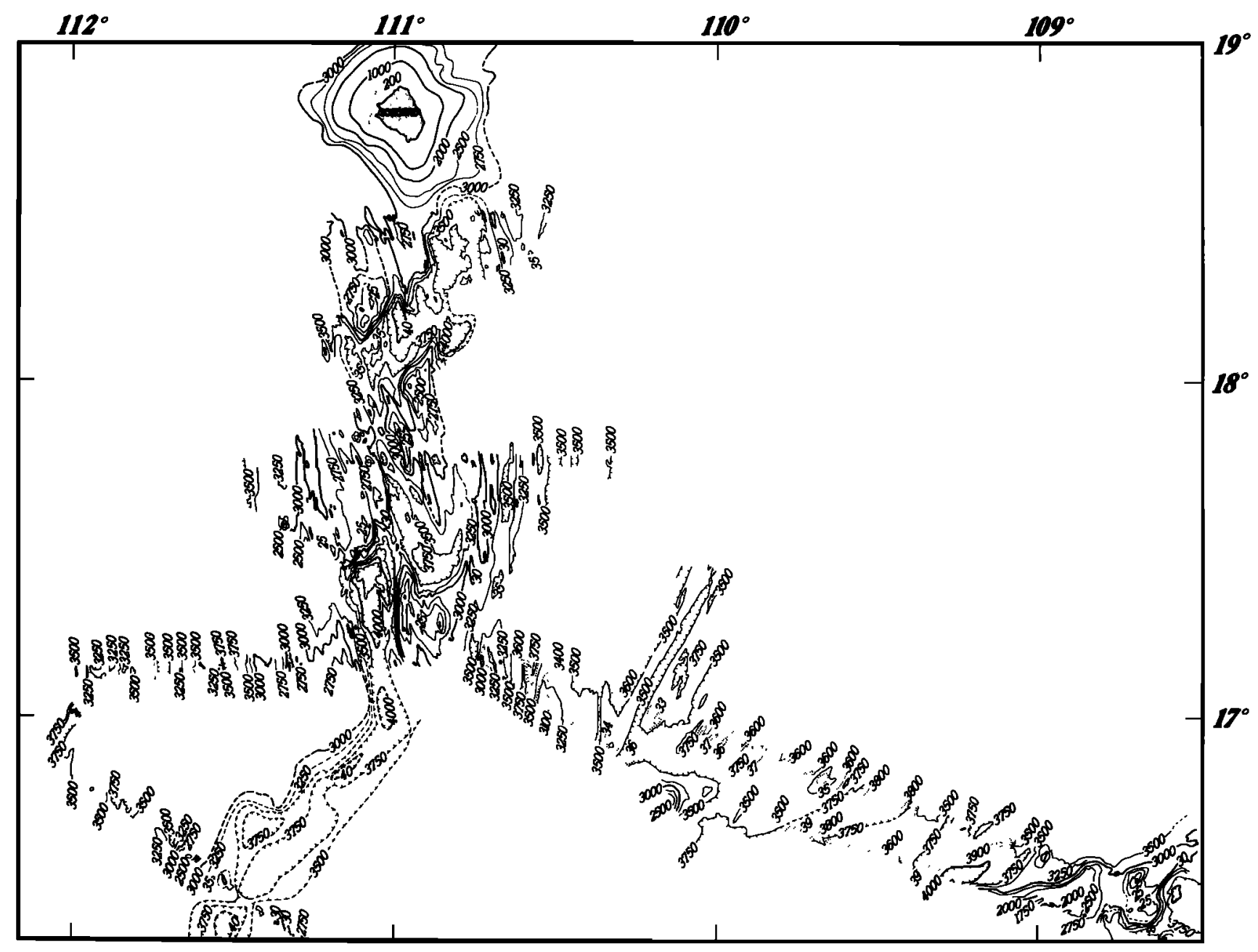

Fig. 3. Sea Beam survey of the abandoned Mathematician spreading center. Tracks are on Figure 4. Solid lines are Sea Beam contours. Dashed lines are interpolated contours.

younger than anomaly 3 , perhaps $2 \prime 3$, or 3.15 m.y. ago. A pattern of progressive northward extinction is thus confirmed, matching the northward propagation at the Moctezuma Trough, although some of the age determinations are at variance from Klitgord and Mammerickx [1982].

Forward modeling of the long Vema 28 profile (Figure 5) is compatible with spreading rates of $\sim 65 \mathrm{~mm} / \mathrm{yr}$ till $8 \mathrm{~m}$.y., $45 \mathrm{~mm} / \mathrm{yr}$ till $4.21 \mathrm{~m} . y$. and a final slowing of $25 \mathrm{~mm} / \mathrm{yr}$ till extinction, at that latitude, $3.5 \mathrm{~m}$.y. ago. As late Miocene and Pliocene spreading rates north of the Rivera fracture zone do not fluctuate, the slowing of spreading rates at Mathematician Ridge implies that Pacific-Farallon spreading (or Pacific-Guadalupe in the nomenclature of Klitgord and Mammerickx [1982]) is occurring contemporaneously elsewhere at the same latitude. We will document more fully and later on that, as the Mathematician Ridge failed, a new Pacific-Farallon spreading ridge (the EPR) formed by propagation at the site of the Moctezuma Trough, to the east (Figure 2).

This interpretation is supported by evidence of slow spreading found by Batiza and Vanro [1985] in rock samples dredged from the inner slopes of the Mathematician rift. He argues that the relative freshness of the midocean ridge basalt lavas and their primitive composition suggest that they were erupted in the last stages of rift abandonment after the disappearance of the shallow crustal magma chamber that may have been present when the rift was fast spreading.

\section{Region BetweEn The Mathematician Ridge AND THE MoCTEZuMa Trough}

The region east of the Mathematician failed rift is a fragment of the much larger Farallon plate that was transferred to the Pacific plate as the new EPR propagated northward. Only a few Sea Beam swaths cross it, and directions of abyssal hills are shown in Figures 3 and 6 and synthesized in Figure 4. Three hundred kilometer long segments of magnetic lineations from anomaly $3^{\prime}$ to anomaly $5 \mathrm{~A}$ are well identified on the eastem flank of the Mathematician Ridge (Figure 4). They show a general $\mathrm{N} 33^{\circ} \mathrm{E}$ trend as determined by Klitgord and Mammerickx [1982]; the apparent broad curvature may be due to small fracture zone offsets not yet identified. The only major fracture zones are observed near the Moctezuma Troughs at $16^{\circ} 10^{\prime}$ and $16^{\circ} 30^{\prime} \mathrm{N}$ (Figures 4 and 6). Magnetic lineation and abyssal hill trends are congruent as shown in Figure 4. 


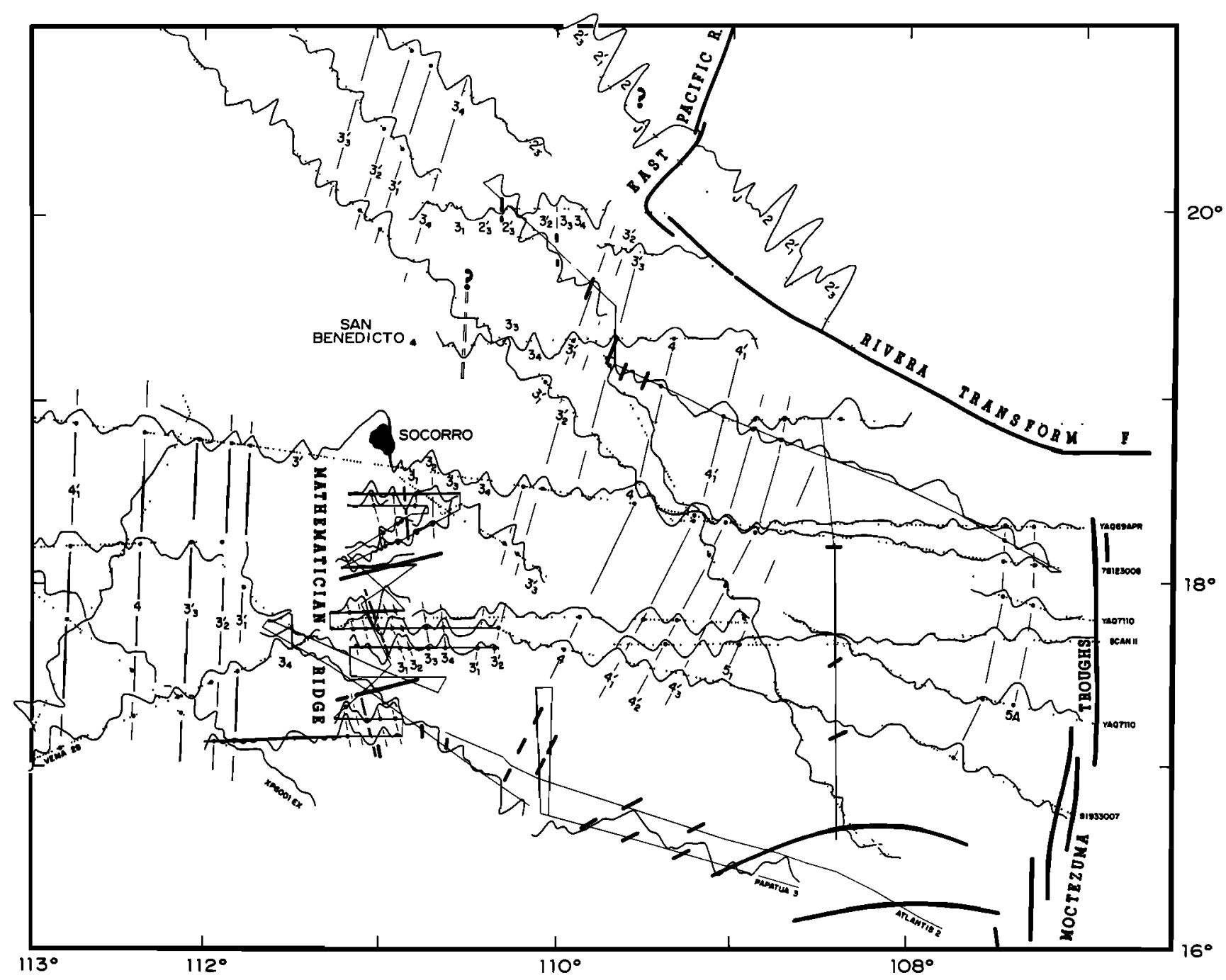

Fig. 4. Magnetic profiles and lineations from the Mathematician Ridge to the Moctezuma Trough. Solid lines are ship tracks with Sea Beam data. Dashed lines are ship tracks with conventional bathymetry and magnetics. Short dark dashes show the direction of abyssal hills, from Sea Beam data.

West of the failed rift, magnetic anomalies $4^{\prime}, 4$, and 3 trend $\mathrm{N} 3^{\circ} \mathrm{E}$. At anomaly 5 time, magnetic lineations east and west of the Mathematician spreading ridge were developed with respect to a northern Pacific-Farallon pole of rotation [Engebretson et al., 1984]. Anomalies east and west of the Mathematician Ridge should show a pattern converging to the north, but this is not observed.

In summary, topographic and magnetic lineations are congruent on the fragment of transferred Farallon lithosphere; they progressively change orientation east to west, from a NE trend to a NW one. While magnetic lineations are continuous on eastern older crust, three short and now inactive transform faults offset the Mathematician Ridge at anomaly 3 time.

\section{The Moctezuma Trough ANd Abyssal HIIIS To The EAsT}

The identification of long-distance spreading center jumps came from the observation on the seafloor of major troughs, subparallel to magnetic anomaly lineations. Mammerickx and Sandwell [1986] have discussed several profiles across some of these features in the context of a model for the birth and evolution of long-distance spreading center jumps.

The understanding of the morphology of rift initiation sites has evolved from an examination of the morphology of

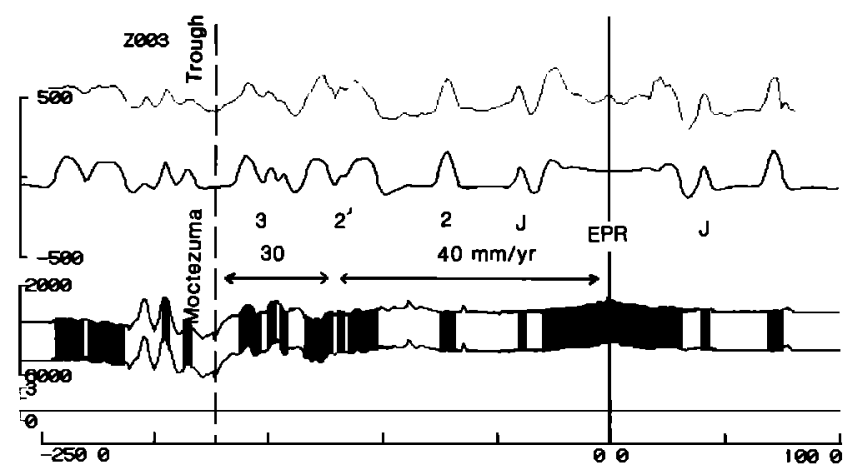

Fig. 5. Magnetic profile, model, and bathymetric profile of Vema 2810, located in Figure 4. Spreading rates in $\mathrm{mm} / \mathrm{yr}$ are shown for various sections of the profile, from the Mathematician failed rift to the Moctezuma Trough. 


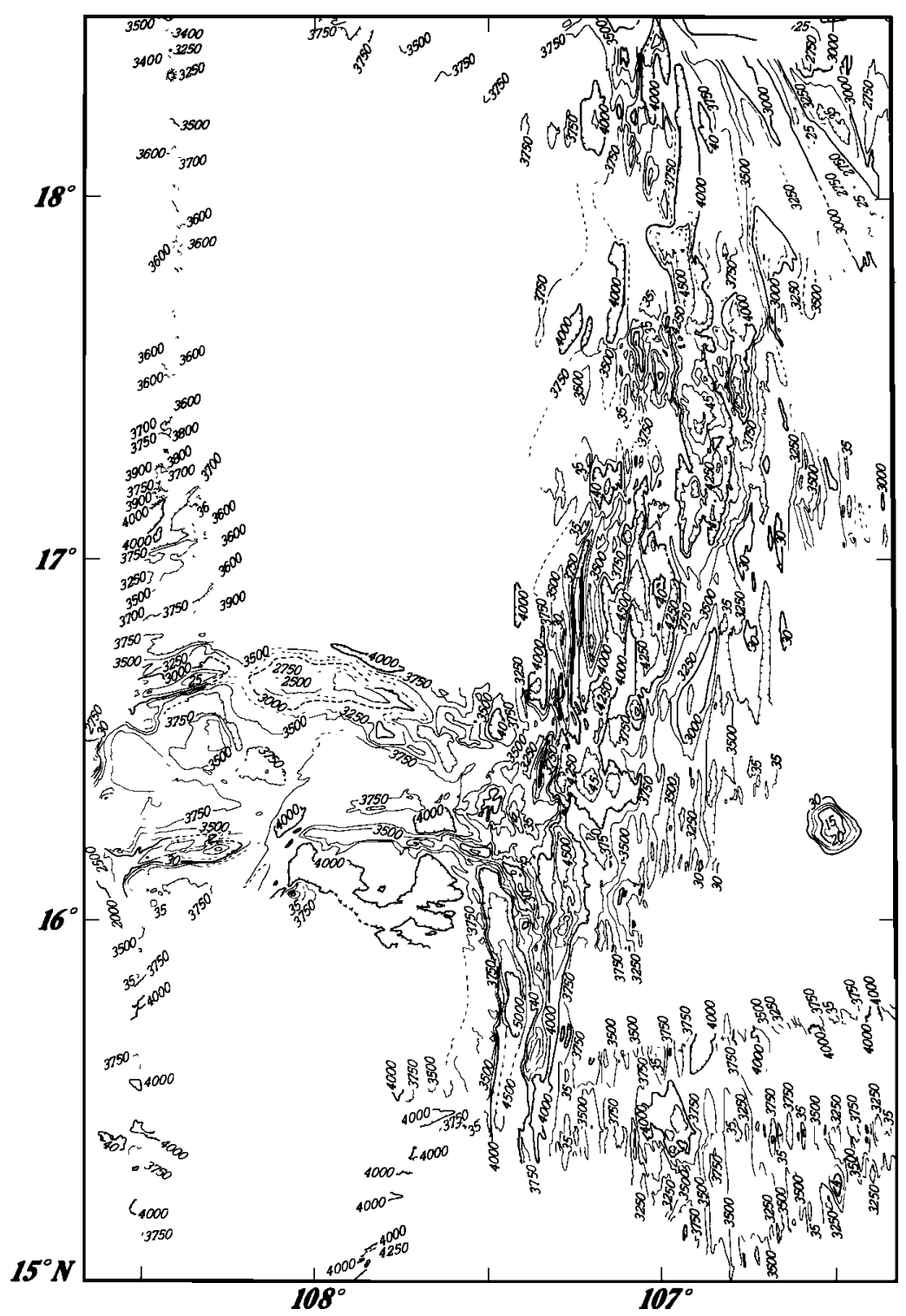

Fig. 6. Sea Beam survey of the Moctezuma Trough. Ship tracks are in Figures 4 and 7.

short-distance spreading center jumps along the EPR at ments of the Moctezuma Troughs [Mammerickx, 1984] $18^{\circ} \mathrm{N}$ [Mammerickx, 1984]. An axial volcano emerges from were surveyed earlier with the Sea Beam system. A more the depression that marks a propagating tip; as the new extensive survey of these troughs is shown in Figures 6 and ridge propagates, the axes of two flanking depressions en- 7 . The morphology of this rift initiation site is not a single close a wedge of new crust generated by the new spreading depression as that observed at short spreading ridge jumps, center. The axes of these depressions are the morphological but rather a complex set of deep troughs. From $15^{\circ} 30^{\prime} \mathrm{N}$ to equivalent of Hey's pseudofaults $[\mathrm{Hey}, 1977 \mathrm{a}]$. The Orozco $18^{\circ} 30^{\prime} \mathrm{N}$ the troughs show a consistent pattern of imbricatpropagator shows a similar morphology [Madsen et al., ed, en echelon deeps. Moving northward as a trough shoals, 1986]; (Figure 2). Hey et al. [1986] also recognize a bathy- a deeper eastern trough parallels it, extends farther north, metric expression to the Galapagos pseudofaults, although and shoals in turn. The pattern is repeated several times. At they distinguish a well-defined outer pseudofault from a $16^{\circ} 10^{\prime} \mathrm{N} / 108^{\circ} \mathrm{W}$ and $16^{\circ} 30^{\prime} \mathrm{N} / 108^{\circ} \mathrm{W}$, two east trending more diffuse inner pseudofault. ridges appear to be fracture zones on the captured fragment

The Moctezuma Trough or Troughs mark the site where of Farallon plate. Mammerickx [1984] observed oblique new spreading initiated as the Mathematician Ridge failed. lineations at $16^{\circ} \mathrm{N}$ between $107^{\circ} 30^{\prime} \mathrm{W}$ and $107^{\circ} 50^{\circ} \mathrm{W}$ that Depending on the context, we will discuss the Moctezuma now appear to belong to that fracture zone topography. Trough, in the singular, as the western part of the rift initiation site, or the Moctezuma Troughs, to stress the complexity or the multiple elements of that site. The same will be north of $17^{\circ} 40^{\prime} \mathrm{N}$. South of the detailed survey, occasional true for the Michoacan Trough or Troughs. Two short seg- Sea Beam transits and conventional bathymetric data al- 


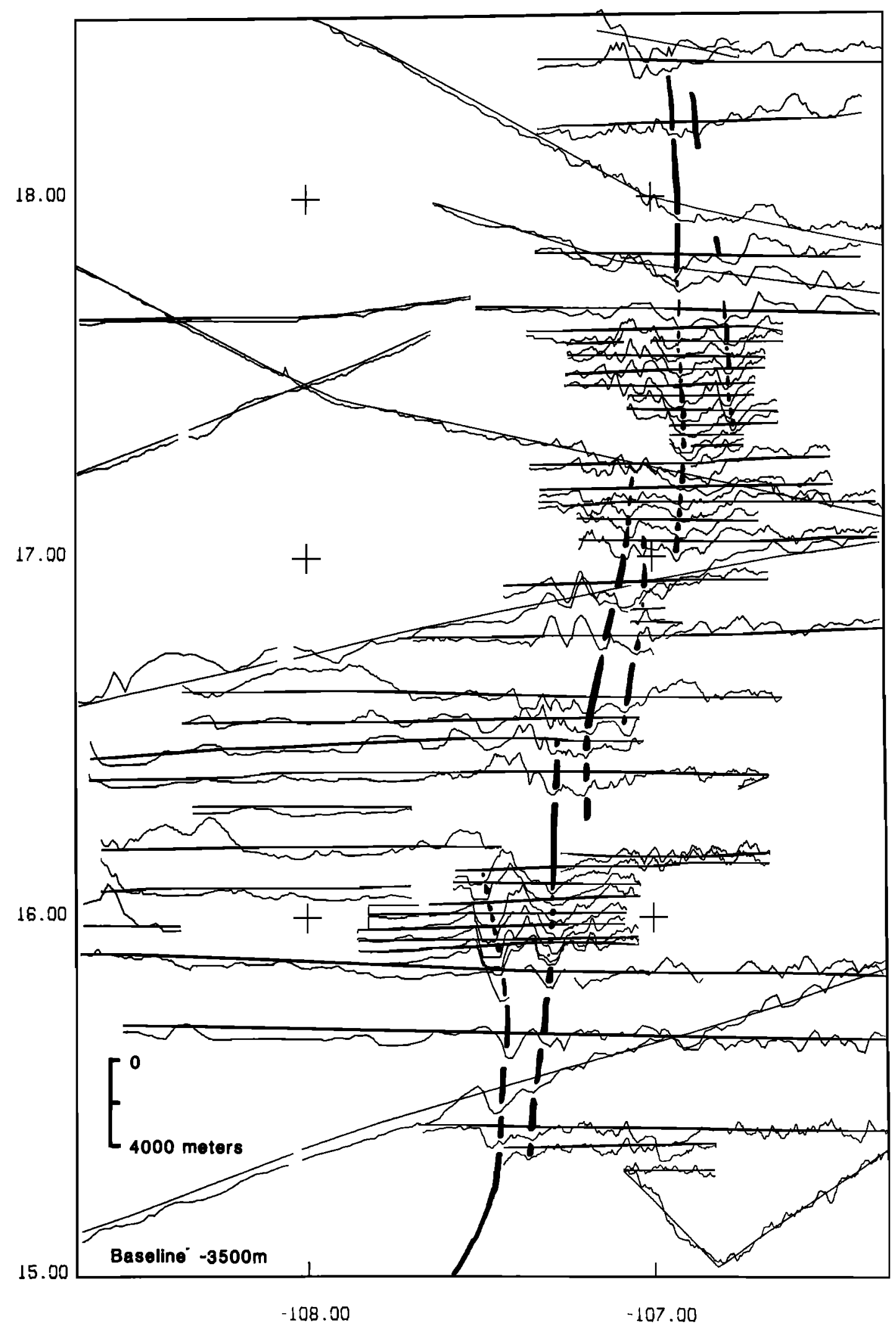

Fig. 7. Selected bathymetric profiles across the Moctezuma Troughs. Heavy north-south lines are major trough axes as in Figure 6. 


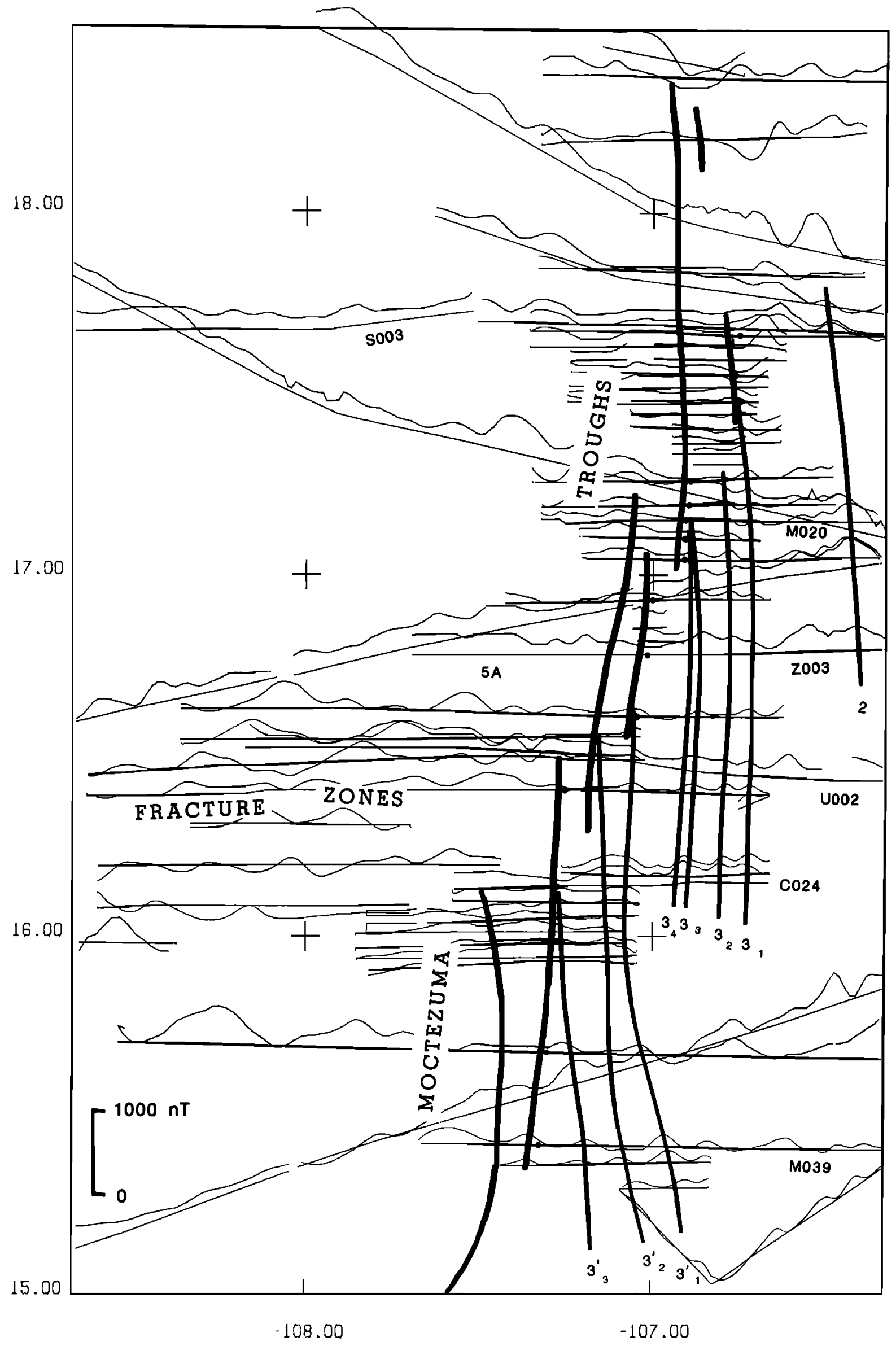

Fig. 8. Magnetic profiles across the Moctezuma Trough. Heavy lines are major trough axes as in Figures 6 and 7. Dots mark where recognizable spreading started at the new ridge. 

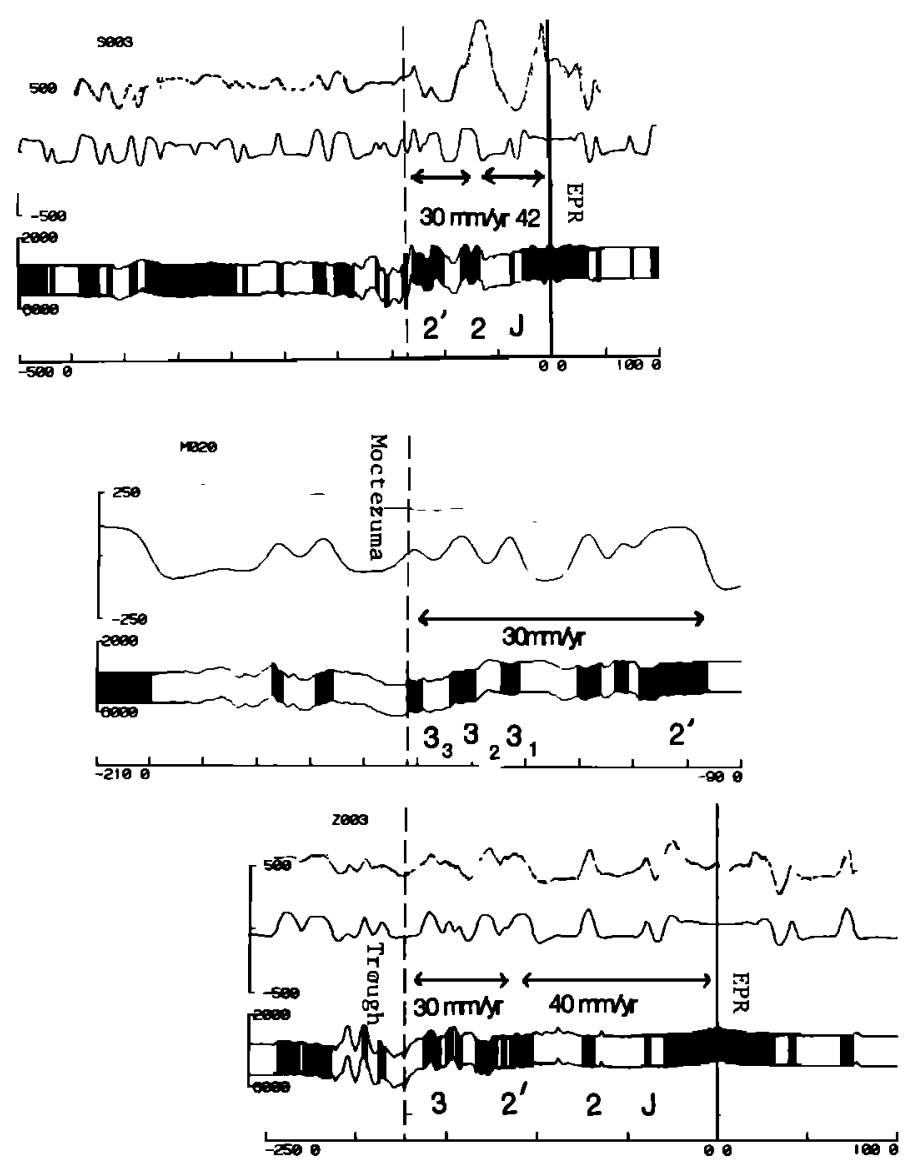
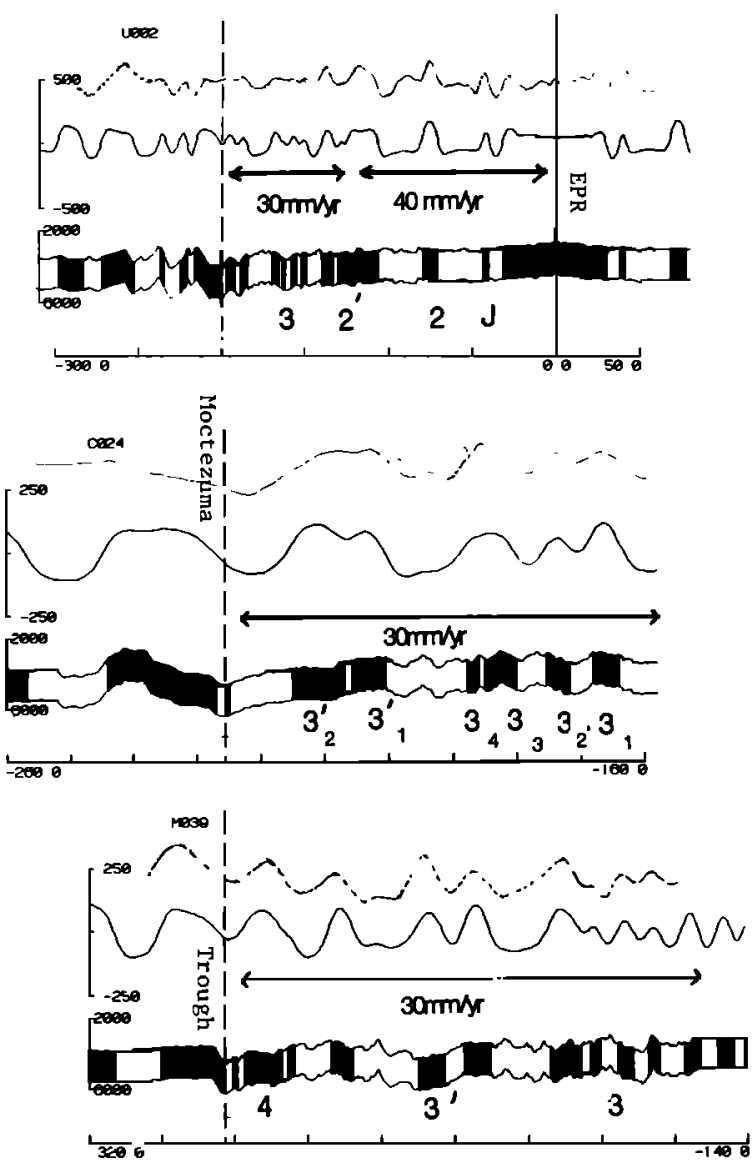

Fig. 9. Magnetic profiles and models east of the Moctezuma Trough. For each set the top profile is the actual data (in nanoteslas). The niddle profile is the model. The lower profile is the bathymetry, in meters; darkened blocks are normal magnetic polarity. Horizontal axis is in kilometers. Profiles are identified in Figure 8. Numbers between arrows indicate spreading rate for that section in $\mathrm{mm} / \mathrm{yr}$.

lowed us to extend the Moctezuma Troughs (Figure 2): from $15^{\circ} 30^{\circ} \mathrm{N}$ to $14^{\circ} \mathrm{N}$ the troughs make a sharp westward bend and end at the western end of the West O'Gorman fracture zone.

Magnetic anomaly lineations on either side of the Moctezuma Troughs are shown in Figures 2 and 8 . The oldest identified anomaly is 5A, west of the Moctezuma Troughs: anomalies are progressively younger toward the Mathematician Ridge. East of the Moctezuma Troughs, the oldest anomaly is 5 to the south $\left(14^{\circ} \mathrm{N}\right)$ and $2^{\prime}$ to the north; progressively younger anomalies disappear northward in a pattern associated with propagation. The Orozco fracture zone is not evident in either bathymetry or magnetic data on crust older than 5 m.y. (anomaly 3); it must be a relatively recent feature.

The magnetic anomaly profiles shown in Figure 9 were forward modeled by generating and matching synthetic magnetic anomaly profiles which are calculated using the two-dimensional bathymetry, a 1.7-km-thick magnetic layer and effective susceptibility of $0.01 \mathrm{emu}$, and the Mankinen and Dalrymple [1979] time scale; it is a recalculation of $\mathrm{La}$ Brecque et al. [1977]. Other time scales could have been used; it would only have a minor effect on the spreading and propagating rates. All data presented in Figure 9 are projected on east-west lines, and the synthetic models were generated assuming east-west spreading. Although we realize that small local adjustments may have occurred before, during, and after the major, large-offset rift jump, we modeled the data assuming that only one rift jump occurred. These local adjustments are modeled as slower or faster episodes of spreading. This was done to simplify the modeling and emphasize the major components of this large-scale ridge jump. More detailed magnetic anomaly modeling will only be possible after analyzing the data across the Michoacan Trough, the matching rift initiation site east of the EPR (Figure 2). That work will enable us to determine if the multiple depressions of the Moctezuma Troughs are old broken (stretched?) Farallon lithosphere [Mammerickx and Sandwell, 1986] or if it is new Pacific plate lithosphere that grew in a chaotic manner due to very slow spreading and/or multiple episodes of small offset propagation.

The correlation of spreading rate and topography roughness [Menard, 1967] is clearly displayed on the three long profiles in Figures 8 and 9 (S003, Z003 and U002). The two profiles, Z003 at $16^{\circ} 47^{\prime} \mathrm{N}$ and $\mathrm{U} 002$ at $16^{\circ} 26^{\prime} \mathrm{N}$, are of particular interest. They both show smoother topography over the parts of the profiles with half spreading rates of $40-45$ $\mathrm{mm} / \mathrm{yr}$ on crust younger than anomaly $2^{\prime} 2$. That crust was generated during the period of single EPR spreading which followed the failure of the Mathematician Ridge 3.15 m.y. 
ago. These profiles also show that rougher topography was formed during the earlier period of slower and dual spreading (half rates $\sim 30 \mathrm{~mm} / \mathrm{yr}$ ). Furthermore this period of slower and dual spreading shortens northward: it started earlier on the U002 profile than on the Z003 profile. This results in a narrowing to the north of the zone of rough topography (Figure 2). A line connecting the points where spreading rates change from relatively slow dual spreading to relatively fast full spreading is also a morphological boundary between areas of rough and smooth topography. We identify it as the rough-smooth boundary in Figure 2 . This rough-smooth boundary when fully surveyed should record the time of extinction of spreading at the Mathematician Ridge several hundred kilometers west of it.

The northernmost profile, $\mathrm{S} 003$ at $17^{\circ} 40^{\prime} \mathrm{N}$ (Figures 8 and 9), shows further complexities. Here, slow spreading is shown to have operated from the young side of anomaly 2 to the old side of anomaly $2^{\prime}$, at a time when the Mathematician Ridge had already failed. This implies that the now single East Pacific spreading center must have been spreading asymmetrically.

\section{North and South Boundaries}

The Sea Beam surveys undertaken during the Papatua 3 Expedition were focused on the midsections of the Mathematician Ridge and the Moctezuma Troughs. Our knowledge of the northem and southern boundaries of the paleoplate is limited to the analysis of the bathymetric data collected with conventional depth recording systems. A recent bathymetric chart of the area shows two prominent features: the Rivera and West O'Gorman fracture zones (Figure 2) [Mammerickx and Smith, 1982]. The two features are subparallel and define small circles about a PacificFarallon late Neogene pole of rotation.

The Rivera fracture zone originated as a major spreading ridge offset quite recently. At anomaly 3 time, at $-20^{\circ} \mathrm{N}$ and $110^{\circ} \mathrm{W}$ (Figure 2), magnetic anomalies were not significantly offset, and north of the Rivera fracture zone, spreading occurred along a ridge in line with the Mathematician Ridge. The Rivera fracture zone started as the northern boundary of the Mathematician microplate. It is only since the cessation of spreading at the Mathematician Ridge that full spreading occurred east of the Moctezuma Trough exclusively.

The Rivera fracture zone is made of several segments. From $110^{\circ} 10^{\prime} \mathrm{W}$ to $109^{\circ} 20^{\prime} \mathrm{W}$ the fracture zone shows no distinctive high-amplitude topographic signature on the records of conventional depth recording systems. From $109^{\circ} 20^{\prime} \mathrm{W}$ to the Moctezuma Trough, the presently active Rivera Transform Fault is characterized by a 5000 -m-deep trough typical of long offset transform faults. From $107^{\circ} \mathrm{W}$ to the present-day southern segment of the EPR, the Rivera Transform Fault, changes character again; it is shallower and poorly constrained.

Between the failed Mathematician Ridge and the Moctezuma Trough, the southern boundary of the Mathematician paleoplate has not yet been defined (Figures 2 and 10). Wrest O'Gorman fracture zone $-106^{\circ} \mathrm{W}$, one observes an unusual feature, the West is at the longitude of $106^{\circ} 25^{\prime} \mathrm{W}$ (arrow on Figure 10), that $\mathrm{O}^{\prime}$ Gorman fracture zone. It has the morphology of a large is, west of anomaly 3 on the SCAN10AR track. The next offset fracture zone with an axial depth of $4750 \mathrm{~m}$ and two and nearest topographic profile is at $105^{\circ} 30^{\prime} \mathrm{W}$ (arrow on bounding ridges, a high one to the south, and to the north the low-amplitude ridge corresponding to bent lithosphere [Sandwell and Schuberst, 1982]. Yet the anomalies offset north and south of it are minimal.

\section{Residual Features East of the EPR}

A number of matching topographic and magnetic features are observed on the eastern flank of the East Pacific Rise (Figure 2). They mirror some of the features on the western side and are the rough-smooth boundary where spreading rate changes occurred, the zone of relatively rough topography and slow spreading, and the matching eastern half of the rift initiation site, the Michoacan Trough. No new data were collected to give a detailed description of these features.

\section{Discussion}

All of the elements of the Mathematician region have now been individually described, and a picture of the Mathematician paleoplate emerges.

\section{Western and Southern Boundary of the Paleoplate}

The western boundary of the paleoplate is the jagged line formed by the axis of the Mathematician failed rift and its transform segments (Figure 2). The time of extinction of the ridge to the north appears to be $3.15 \mathrm{~m}$.y. ago, on the young side of anomaly 2'3 [Berggren et al., 1985] (Figures 2 and 4).

The surveyed part of the Mathematician failed ridge shows a morphological resemblance with the failed segments of the Cocos-Nazca (Galapagos) spreading center [Hey et al., 1986]; it failed discontinuously and underwent a counterclockwise rotation during the episode of dual spreading when slower rates were in effect both at the failed and propagating ridge (Figure 2). As it rotated counterclockwise, the 300-km-long Pacific-Farallon Ridge segment broke into shorter $\sim 60-\mathrm{km}$ segments, offset by oblique faults. Such oblique faults are common on slow to medium spreading crust [Searle, 1986] and are caused by changes in spreading directions [Menard and Atwater, 1969].

Although the southem end of the Mathematician Ridge has not been surveyed, its time of extinction can be inferred from the analysis of the West O'Gorman fracture zone (Figure 10). We speculate that the West O'Gorman fracture zone started to form and operated during the Neogene for the length of time during which there was dual and relatively slow spreading north of it and relatively fast and single spreading south of it. The eastern termination of this inactive transform fault would then correspond to the time and location where and when dual spreading ceased between Rivera and O'Gorman, at that latitude, and when the East Pacific Rise started operating at full rate as a single PacificFarallon spreading ridge.

The field data partly substantiate that hypothesis, although not unequivocably. The easternmost ship track 


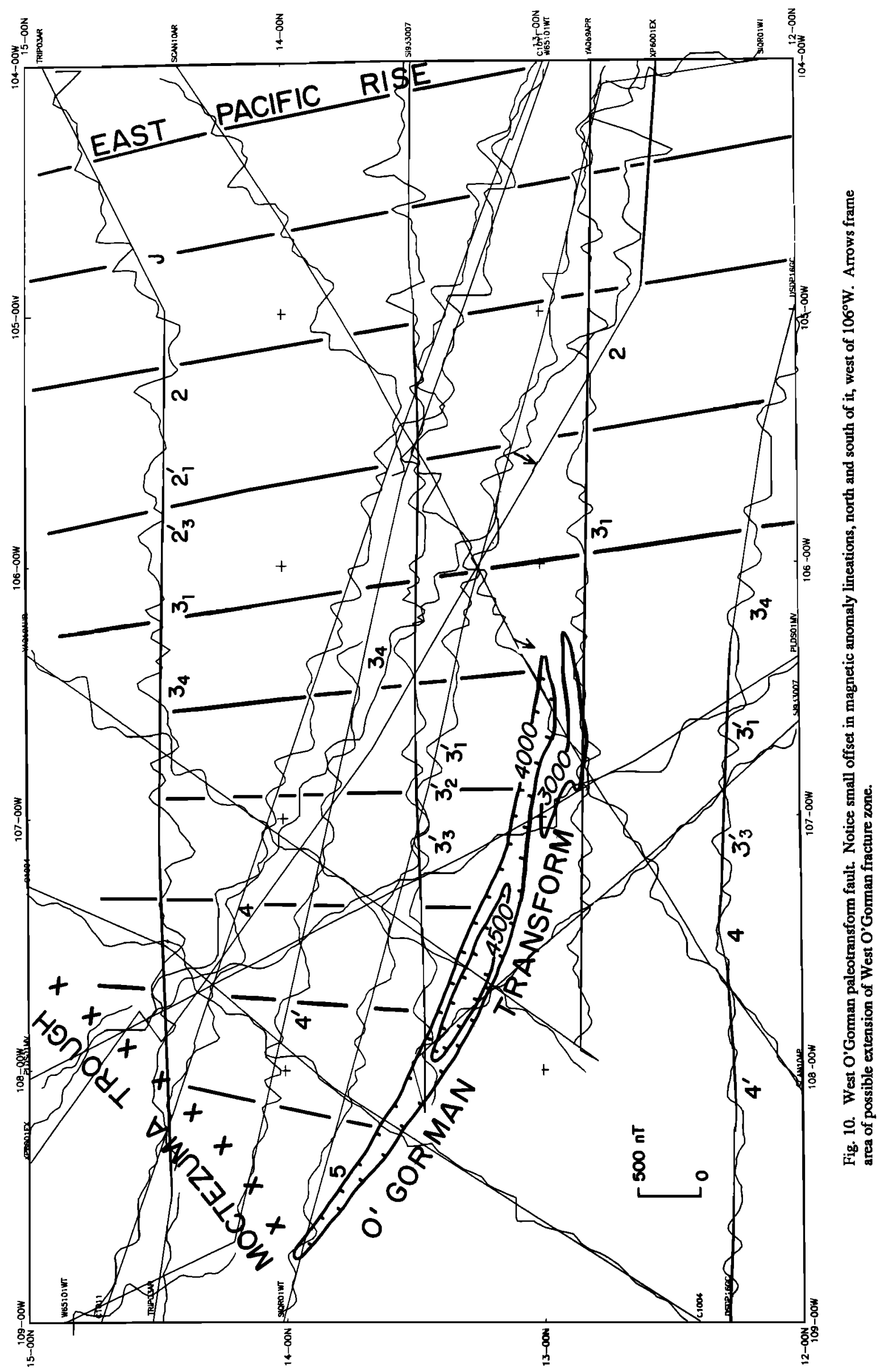




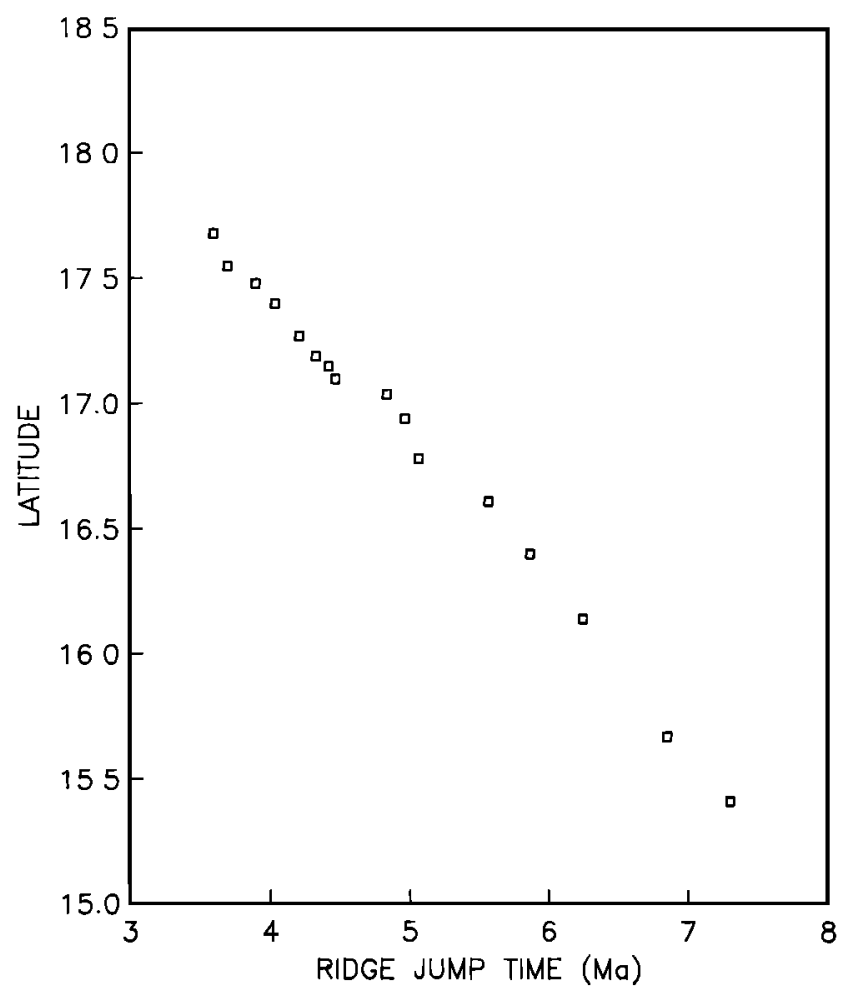

Fig. 11. Propagation rates along the Moctezuma Trough (Sea Beam survey). Squares are black dots of Figure 8.

Figure 10), and it shows no topographic signature indicative of the presence of the O'Gorman fracture zone at that latitude. Although we have not exactly documented the eastemmost end of the O'Gorman fracture zone, we know that it was still active $5 \mathrm{~m}$.y. ago and may have existed until the age of extinction of the northern Mathematician Ridge 3.15 m.y. ago.

The magnetic anomalies north of the O'Gorman fracture zone are well navigated and correlate well. South of it, the YAQ69APR track (Figure 10) is poorly navigated, and the exact longitude of the anomalies' lineation is doubtful. Anomaly 4, south of the O'Gorman fracture zone, is offset by a few miles to the west with respect to its northern counterpart, but because of poor navigation, the case is difficult to make for anomaly $3^{\prime}$.

Only a systematic survey of the northern ends of the failed rift, the Moctezuma Troughs, and the conjugate Michoacan Troughs will resolve these difficulties.

\section{Eastern Boundary of the Paleoplate}

The eastern boundary of the paleoplate separates crust generated during dual spreading (slow) from crust generated during full (fast) spreading. On either side of this boundary the abyssal hills have different amplitudes and wavelengths [Menard, 1967]; this rough-smooth boundary is a spreading rate change boundary. We have only a few observed data points on that eastern boundary, and we do not know yet whether it is a straight or a jagged line. When documented by more extensive surveys, the rough-smooth boundary should record with much detail the time of extinction of the
Mathematician failing ridge $400 \mathrm{~km}$ to the west. Corresponding to the beginning of slow spreading at the new spreading ridge, boundaries marking spreading rate changes should be observed east and west of the failed ridge. Because of the complexity of the Mathematician Ridge and the limited survey, this is not completely documented.

\section{The Moctezuma Troughs: A Mid-Paleoplate Feature}

The multiple Moctezuma Troughs are developed between the failed rift and the rough-smooth boundary. Mammerickx and Sandwell [1986] attributed the origin of one of the troughs to a residual feature of the original propagating rift tip, out of which a new spreading ridge developed: Hey's [1977a] pseudofault would be the line at the foot of broken-up old crust, at the bottom of the trough from which a new ridge rises. Troughs to the west were attributed to prerifting normal faulting on the area of the seafloor where rifting and spreading were about to occur.

Figure 11 is a plot of ridge initiation versus latitude for the magnetic data. Latitudes are those at which the profiles of Figure 8 intersect the easternmost Moctezuma Trough scarp (or the dotted line, where different from the easternmost trough as explained in Figure 8). Ridge jump times were obtained from the magnetic models for the profiles in Figures 8 and 9. This plot documents that the gross propagation rate of the EPR was about $65 \mathrm{~km} / \mathrm{m}$.y. from $7 \mathrm{~m} . y$. to $3.5 \mathrm{~m}$.y. ago. It is interesting to note that the three data points south of $17^{\circ} \mathrm{N}$ are aligned in a steeper orientation with respect to the general overall trend. Although this may be scatter in the data, the fact that it is just to the north of the east-west structures at $16^{\circ} 10^{\prime} \mathrm{N}$ and $16^{\circ} 30^{\prime} \mathrm{N}$ (Figure 6) suggests that the northward propagation of the EPR slowed down through these east-west structures, then speeded up (no more than $125 \mathrm{~km} / \mathrm{m} . y$. ), and then slowed down to the previous overall rate. This suggestion is speculative and not well constrained. It is not clear at this time whether these two east-west structures are fracture zones offsetting the Mathematician Ridges or whether the paleoplate evolved in two episodes, and that we observe here an intermediate paleoplate boundary.

The remarkable result of Figure 11 is that although there are local tectonic complexities, the overall propagation rate of the new EPR spreading ridge replacing the failing Mathematician Ridge several hundred kilometers away was nearly constant for over $3 \mathrm{~m} . \mathrm{y}$. The implications of this appear to be that the driving force for propagation is longlived and constant.

This analysis of the magnetics on the eastem flank of the Moctezuma Troughs does not resolve the problem of the origin of multiple troughs. The troughs might indicate very slow early spreading. They might be traces of several consecutive episodes of propagation closely following one another. In these two cases, the thermal contrast between older crust to the west and younger crust to the east would be maximum at the westernmost trough; this is observed at $16^{\circ} \mathrm{N}$, but not from $17^{\circ}$ to $18^{\circ} \mathrm{N}$ (Figure 7). Some of the troughs may have occurred by vertical faulting of old Farallon lithosphere preceding rifting [Mammerickx and Sandwell, 1986]. It is not possible to choose between these interpretations at this time, in this area. The study of the 
comparable Chinook Trough in the northwest Pacific [Mam- Microplates and Paleoplates

merickx and Sharman, this issue] shows that most of the high amplitude topography of that trough is due to very slow spreading in the early stages of spreading at the new rift site.

\section{Rotation of the Fragment of Captured Lithosphere}

Hey et al. [1980] discussed a model where a continuously propagating rift is connected with a progressively dying one by a continuously migrating transform fault. Later, Hey et al. [1986] modified this interpretation in suggesting that the failing and propagating spreading centers at the Galapagos rift overlapped for a certain distance and were connected by a broad zone of nonrigid plate deformation where the abyssal hills were sheared and rotated. A zone of oblique lineations is indeed observed between the propagating and failing rift in the case of short-distance spreading center jumps [Searle et al., 1981; Mammerickx, 1984; Searle and Hey, 1983; Hey et al., 1986; Madsen et al., 1986]. In those cases the zones of transferred lithosphere are relatively high and elevated above the depth of the new spreading ridge axes.

In the case of the Mathematician region, the fragment of captured Farallon lithosphere fits the age-depth subsidence curve [Mammerickx and Sandwell, 1986], and there is a significant vertical offset between the regional depth of the older and deeper lithosphere west of the Moctezuma Troughs and the regional depth of the younger and shallower crust generated after the episode of propagation, east of the troughs.

The abyssal hill trends and magnetic lineations on the fragment of transferred lithosphere show clear signs of a clockwise rotation. The Sea Beam coverage of the area of transferred lithosphere is insufficient to do more than notice a congruence between magnetic lineations and abyssal hills.

\section{Residual Features East of the EPR}

During the microplate stage of the plate boundary reorganization, a number of matching topographic and magnetic features were developed on the eastern flank of the new propagating ridge (Figure 2). These features are now observed to the east of the EPR, and although generated during the spreading reorganization episode, they are not part of the paleoplate. The eastern rough-smooth boundary and the eastern area of slow spreading must have recorded the evolution of the new spreading ridge just as accurately as their western counterparts.

In an asymmetric basin like the Pacific (Figure 12), the western Pacific plate has preserved a long and complex tectonic history in its geomorphology and tectonic lineations, while many of the features recording these same tectonic events on the eastern broken-up Farallon plate have been subducted in the Middle America Trench. We can conceive that in such a setting, the paleoplate part of a spreading reorganization might have been subducted and that only the mirror image set of residual features would be preserved. They would be sufficient to reconstruct a significant part of the vanished paleoplate history. In the Mathematician region, of course, both paleoplate and mirror residual features are left.
The Mathematician paleoplate and its boundaries show several striking similarities and several differences with the northern part of the Easter plate [Hey et al., 1985; Naar and Hey, 1986]. The comparisons are facilitated by similar geometries. In both cases we observe dual spreading with ridge segments $-400 \mathrm{~km}$ long. The eastern ridges are the new ones, while the western ones are either extinct or in the process of extinction. The distance between dual spreading ridges at the time they were both active is about 300 to 400 $\mathrm{km}$. Between the two ridges is an area of lithosphere, transferred from the eastern plate to the western plate.

The major difference between the two areas is one of age. In the case of the Easter plate both spreading ridges are still active; the microplate is the region between the two active ridges. In the Mathematician area, there is no dual spreading anymore. The western ridge ceased spreading a few million years ago, and full spreading presently occurs at the EPR only. Assuming that the Mathematician paleoplate can be used as a model, the Easter microplate will evolve into a paleoplate when the plate reorganization is completed and full spreading resumes at the single eastern spreading ridge.

\section{Other Paleoplates}

Several sets of abandoned spreading ridges and rift initiation sites have been reported in the Pacific (Figure 12) and Indian oceans [Mammerickx and Sandwell, 1986]; they are the most conspicuous features revealing the likely presence of other paleoplates. Abandoned spreading ridges and rift initiation site sets are mostly recognized in analyzing surface ship data, and we need to confirm their origin and evolution in a paleoplate type scenario by identifying in each case the remainder of the diagnostic features of paleoplates: rotated magnetic anomalies and abyssal hills, the spreading rate variations, and the rate change boundary. We will discuss several Pacific basin examples east of the western Pacific major subduction zones, excluding back arc spreading.

The most common geometry for spreading reorganizations is the one most frequently observed at active microplates: two quasi-parallel spreading ridges bound by transform faults and defining a quadrilateral area (Figure 13a). In the northwest Pacific, at the Chinook plate, one observes the configuration of a triple junction jump with a complex evolution of the various plate boundaries [Mammerickx and Sharman, this issue] (Figure 13b). Another configuration is the one observed at the origin of the Cocos-Nazca spreading ridge [Hey, 1977b] (Figure 13c), where a fracture zone offsetting a spreading ridge becomes a spreading initiation site. Still another configuration is the one proposed by Hilde et al. [1977] (Figure 13d) for the origin of the Pacific plate and where a triangular microplate is bound by three active spreading ridges. The small number of paleoplates discussed and the very preliminary understanding that one has of most of them prevent us from reaching definitive conclusions. Yet it is worth noticing that while the reorganizations in Figure $13 a$ and $13 b$ result in the creation of paleoplates, the configurations in Figures $13 c$ and $13 d$ do not. The Pacific microplate in Hilde et al.'s 


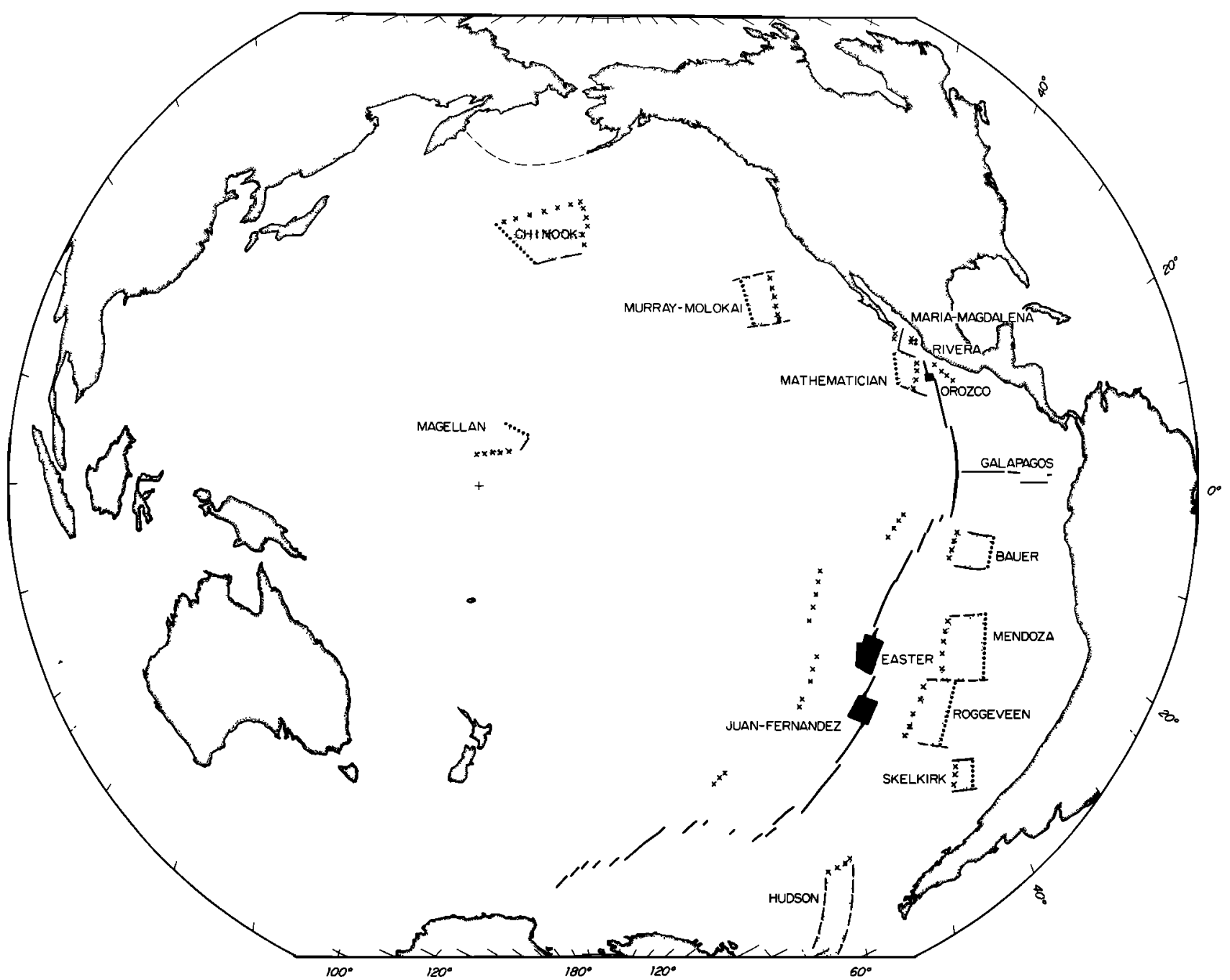

Fig. 12. Pacific basin with sketch of probable paleoplates. Dotted lines are abandoned spreading ridges, crosses are rift initiation sites. Zones of initial slow spreading are not identified. Dark areas are active microplates on the East Pacific Rise and CocosNazca spreading ridge. Dotted pattern areas are paleoplates.

[1977] speculations has grown to occupy most of the Pacific basin.

Active microplates and paleoplates occur in a range of sizes, from the $-20-\mathrm{km}$ active-failed ridge offset at the Galapagos site [Hey et al., 1986] to the $400-\mathrm{km}$ ridge jump at the Mathematician plate to the $2000-\mathrm{km}$ triple junction "jump" at the Chinook plate (for a detailed study of the Chinook paleoplate, see Mammerickx and Sharman [this issue], and Figure 12). Although differences between small and large microplates exist, they do not appear to be very significant. A major difference between the two types is in the complexity of the rift initiation site topography: complex where there is early slow spreading and a distance of hundreds of kilometers between the failed rift and the new one, simple where the distance is a few tens of kilometers.

There are enough well-surveyed microplates that we see a pattern of evolution emerge, from the initiation of a new rifting site with an incipient microplate to a paleoplate; we will use examples within or near the Pacific basin. Luhr et al. [1985] and Allan [1986] have investigated the Colima and other grabens in southwest Mexico and speculated that they represent the onset of rifting (Figures 2 and 12); these grabens are at the initial stage of a spreading reorganization which will evolve in a spreading ridge jump, from the present EPR location, between the Tamayo and Rivera fracture zones, to the Colima Trough. The Orozco region shows a later stage of the phenomenon; a propagator has just overshot the southern branch of the Orozco fracture zone but has not reached its northern branch [Madsen et al., 1986]. The Easter plate is the next stage; both ridges are active, and the quadrilateral configuration is completed [Hey et al., 1985; Naar and Hey, 1986]. The Galapagos propagator is the next stage; one of the ridges has failed over some of its length but is still active over a short segment [Hey et al., 1986]. The process is completed at the Mathematician paleoplate; full spreading has resumed at the dominant ridge, and all features documenting the reorganization episode are inactive, yet still present and nearby. The Chinook plate reorganization has occurred so long ago (80 m.y.) that the active ridge is located thousands of miles 

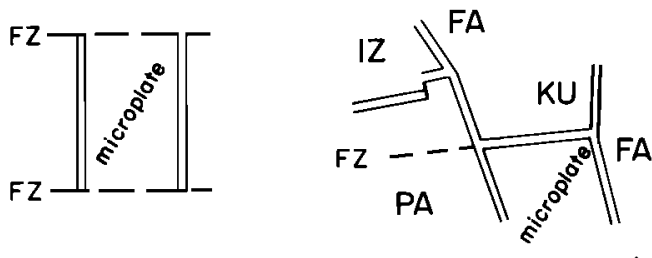

$\boldsymbol{a}$
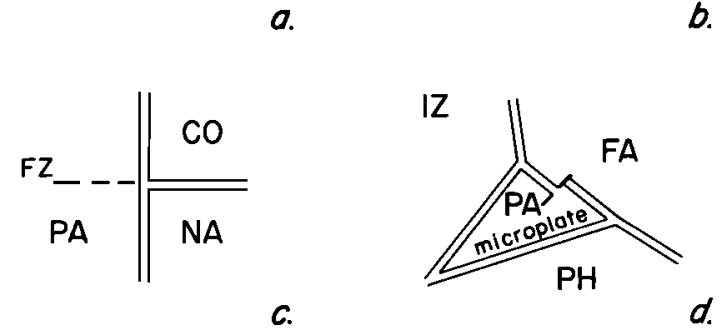

The Sea Beam surveys show a directional change in the Mathematician Ridge orientation just before extinction. Several examples of paleoplates are observed in the Pacific basin.

Smaller-scale linear topographic features tens of meters high and tens of kilometers long are also associated with paleoplates, but they can only be identified with higherresolution swath systems like the Sea Beam or the SeaMarc. Profiles and limited swath data show that they are abyssal hills with variable amplitude, wavelengths, and orientations which reflect changing spreading rates, changing spreading directions, and plate rotation.

Acknowledgments. Work on this project was funded by NSF grant OCE85-11002 and ONR grants USN-N00014-85-C-0104 and USN-N00014-87-K-0005. Operations in the Mexican Exclusive Economic Zone were conducted under the auspices of diplomatic note 303417. We thank Captain Desjardins and the crew

Fig. 13. Four tectonic configurations. (a) Quadrilateral, as at the Mathematician, Easter, and many other microplates. (b) Jumped triple junction as in the northwest Pacific. (c) Opening of a fracture zone offsetting a linear spreading ridge; rift initiation sites remain as residual features, no paleoplate is created. The opening of the Cocos-Nazca spreading ridge is an example. (d) Triangular microplate bound by active spreading ridges; no paleoplate or residual features are created. The example is the origin of the Pacific plate as in the work by Hilde et al. [1977].

away from the paleoplate; other ridge reorganizations have even occurred in between.

\section{Conclusion}

We define, in the Mathematician seamounts region, a paleoplate, that is, a complex suite of residual topographic and magnetic features that have recorded in detail the major aspects of a past and long concluded episode of spreading reorganization between the Rivera and West O'Gorman fracture zones. That reorganization involved a "jump" in the location of a spreading center, from the Mathematician seamounts to a new site several hundred kilometers away to the east. The paleoplate is the area of seafloor extending from the axis of the failed rift to the boundary where full spreading resumed. It includes not only a fragment of transferred lithosphere but also an area of accreted lithosphere slowly added during dual spreading.

The Mathematician reorganization episode evolved over a period of time that lasted about $7 \mathrm{~m} . \mathrm{y}$. During that period, two parallel spreading ridges operated, defining a shortlived microplate with characteristics common to active microplates now discussed in the literature. At the conclusion of the spreading reorganization episode a single and relocated spreading ridge remained. The paleoplate remains embedded on the west side of the new ridge, the East Pacific Rise. A few related residual features are recorded on the east side, although they do not constitute a paleoplate.

Some of the features associated with paleoplates are first-order topographic features hundreds of meters high and hundreds of kilometers long, easily recognized on single narrow beam echo-sounder crossings. They are the abandoned spreading ridges and the conjugate residual sites where the new spreading ridge propagated into older crust.

of $R / V$ Washington for cooperation during expedition Papatua 03 We also thank J. McClain and P. Lonsdale for releasing Sea Beam data, as well as K. Klitgord and G. Sharman for helpful reviews.

\section{REFERENCES}

Allan, J. F., Geology of the northem Colima and Zacoalco grabens, southwest Mexico: Late Cenozoic rifting in the Mexican volcanic belt, Geol. Soc. Am. Bull., 97, 473-485, 1986.

Anderson, R. N., and J. G. Sclater, Topography and evolution of the East Pacific Rise between $5^{\circ} \mathrm{S}$ and $20^{\circ}$ S, Earth Planet. Sci. Lett., 14, 433441, 1972.

Atwater, T., Implications of plate tectonics for the Cenozoic tectonic evolution of westem North America, Geol. Soc. Am. Bull., 81, 3513-3536, 1970.

Ballard, R. D., and T. H. van Andel, Morphology and tectonics of the inner rift valley at $36^{\circ} 50^{\prime} \mathrm{N}$ on the Mid-Atlantic Ridge, Geol. Soc. Am. Bull., 88, 507-530, 1977.

Batiza, R., and C. G. Chase, Magnetic evidence for a Miocene fossil spreading center south of Isla Guadalupe, E. Pacific near $29^{\circ} \mathrm{N}$, Nature, $289,787-789,1981$.

Batiza, R., and D. A. Vanko, Petrologic evolution of large failed rifts in the eastem Pacific: Petrology of volcanic and plutonic rocks from the Mathematician Ridge area and the Guadalupe Trough, J. Petrol., 26, 564-602, 1985.

Berggren, W. A., D. V. Kent, J. J. Flynn, and J. A. van Couvering, Cenozoic geochronology, Geol. Soc. Am. Bull., 96, 1407-1418, 1985.

Engebretson, D. C., A. Cox, and R. Gordon, Relative motions between oceanic plates of the Pacific basin, J. Geophys. Res., 89, 10,291-10,310, 1984.

Handschumacher, D. W., Post-Eocene plate tectonics of the eastem Pacific, in The Geophysics of the Pacific Ocean Basin and Its Margin, George P. Woollard, vol., Geophys. Monogr. 19, edited by G. H. Sutton, M. H. Manghnani, and R. Moberly, pp. 177-202, AGU, Washington, D. C., 1976.

Herron, E. M., Seafloor spreading and the Cenozoic history of the eastcentral Pacific, Geol. Soc. Am. Bull., 83, 1671-1692, 1972.

Hey, R., A new class of "pseudofaults" and their bearing on plate tectonics: A propagating rift model, Earth Planet. Sci. Lett., 37, 321-325, $1977 a$.

Hey, R., Tectonic evolution of the Cocos-Nazca spreading center, Geol. Soc. Am. Bull., 88, 1404-1420, 1977 .

Hey, R. N., Evidence for spreading center jumps from fine-scale bathymetry and magnetic anomalies near the Galapagos Islands, Geology, 7, 504-506, 1979.

Hey, R. N., and D. S. Wilson, Propagating rift explanation for the tectonic evolution of the northeast-Pacific, The pseudomovie, Earth Planet. Sci. Lett., 58, 167-188, 1982.

Hey, R., K. Duennebier, and W. J. Morgan, Propagating rifts on midocean ridges, J. Geophys. Res., 85, 3647-3658, 1980 .

Hey, R. N., D. F. Naar, M. C. Kleinrock, W. J. Phipps Morgan, E. 
Morales, and J.-G. Schilling, Microplate tectonics along a superfast seafloor spreading system near Easter Island, Noture, 317, 320-325. 1985.

Hey, R. N., M. C. Kleinrock, S. P. Miller, T. M. Atwater, and R. C. Searle, Sea Beam/Deep-Tow investigation of an active oceanic propagating rift system, Galapagos $95.5^{\circ}$ W, J. Geophys. Res., 91, 3369-3393, 1986.

Hilde, T. W. C., S. Uyeda, and L. Kroenke, Evolution of the westem Pacific and its margin, Present State of Plate Tectonics, Tectonophysics, 38, 145-165, 1977.

Klitgord, K. D., and J. M. Mammerickx, Northern East Pacific Rise: Magnetic anomaly and bathymetric framework, J. Geophys. Res., 87, 6725$6750,1982$.

LaBrecque, J. L., D. V. Kent, and S. C. Cande, Revised magnetic polarity time scale for the Late Cretaceous and Cenozoic, Geology, 5, 330-335, 1977.

Lonsdale, P., and K. D. Klitgord, Structure and tectonic history of the eastern Panama basin, Geol. Soc. Am. Bull., 89, 981-999, 1978.

Lowrie, A., T. Aitke, P. Grim, and L. McRaney, Fossil spreading center and faults within the Panama fracture zone, Mar. Geophys. Res., 4, 153-166, 1979.

Luhr, J. F., S. A. Nelson, J. F. Allan, and I. S. E. Carmichael, Active rifting in southwestem Mexico: Manifestation of an incipient eastward spreading ridge jump, Geology, 13, 54-57, 1985.

Macdonald, K. C., K. Kastens., F. N. Spiess, and S. P. Miller, Deep Tow studies of the Tomayo transform faulh Mar. Geophys. Res., 4, 37-70, 1979.

Macdonald, K. C., J. C. Sempere, and P. J. Fox, East Pacific Rise from Siqueiros to Orozco fracture zones: Along-strike continuity of axial neovolcanic zone and structure and evolution of overlapping spreading centers, J. Geophys. Res., 89, 6049-6069, 1984.

Madsen, J. A., P. J. Fox, and K. C. Macdonald, Morphometric fabric of the Orozco transform fault: Results from a Sea Beam investigation, J. Geophys. Res., 91, 3439-3454, 1986.

Mammerickx, J., The morphology of propagating spreading ridges: New and old, J. Geophys. Res., 89, 1817-1828, 1984.

Mammerickx, J., and K. D. Klitgord, East Pacific Rise: Evolution from 25 m.y. B.P. to the Present, J. Geophys. Res., 87, 6751-6758, 1982.

Mammerickx, J., and D. Sandwell, Rifting of old oceanic lithosphere, $J$. Geophys. Res., 91, 1975-1988, 1986.

Mammerickx, J., and G. F. Shamnan, Tectonic evolution of the North Pacific during the Cretaceous quiet period, J. Geophys. Res., this issue.

Mammerickx, J., and S. M. Smith, General Bathymetric Chart of the Oceans (GEBCO), sheets 5-07, Can. Hydrogr. Serv., Ottawa, Ont., 1982.
Mankinen, E. A., and G. B. Dalrymple, Revised geomagnetic polarity time scale for interval 0-5 m.y. B.P., J. Geophys. Res., 84, 615-626, 1979.

Menard, H. W., Sea-floor spreading, topography and the second layer, Science, 157, 923-924, 1967.

Menard, H. W., Fragmentation of the Farallon plate by pivoting subduction, J. Geol., 86, 99-110, 1978.

Menard, H. W., and T. Atwater, Origin of fracture zone topography, $\mathrm{Na}$ ture, 22, 1037-1040, 1969.

Naar, D. F., and R. N. Hey, Fast rift propagation along the East Pacific Rise near Easter Island, J. Geophys. Res., 91, 3425-3438, 1986.

Rea, D. K., Analysis of a fast-spreading rise crest: The East Pacific Rise, $9^{\circ}$ to $12^{\circ} \mathrm{S}$, Mar. Geophys. Res., 2, 291-313, 1976.

Richards, A. F., Geology of the Islas Revilla-Gigedo, Mexico, I, Birth and development of Volcan Barcena, Isla San Benedicto, Bull. Volcanol., 22, 73-123, 1959.

Sandwell, D., and G. Schubert, Lithospheric flexure at fracture zones, $J$. Geophys. Res., 87, 4657-4667, 1982.

Sclater, J. G., R. N. Anderson, and M. L. Bell, Elevation of ridges and evolution of the central eastem Pacific, J. Geophys. Res., 76, 7888$7915,1971$.

Searle, R. C., GLORIA investigations of oceanic fracture zones: Comparative study of the transform fault zone, J. Geol. Soc. London, 143, 743$756,1986$.

Searle, R. C., and R. N. Hey, Gloria observations of the propagating ift at $95.5^{\circ} \mathrm{W}$ on the Cocos-Nazca spreading center, J. Geophys. Res., 88, 6433-6447, 1983.

Searle, R. C., and A. S. Laughton, Sonar studies of the Mid-Atlantic Ridge and Kurchatov fracture zone, J. Geophys. Res., 82, 5313-5328, 1977.

Searle, R. C., T. J. G. Francis, T. W. C. Hilde, M. L. Somers, J. Revie, C. L. Jacobs, M. R. Saunders, B. J. Barrow, and S. V. Bicknell, Gloria, side-scan sonar in the East Pacific, Eos Trans. AGU, 62, 121-122, 1981.

Tyce, R. C., and J. Mammerickx, Morphology of an abandoned spreading center: The Mathematician Ridge, Eos Trans. AGU, 66, 356, 1985.

J. Mammerickx and D.F. Naar, Geological Research Division, A-020, Scripps Institution of Oceanography, La Jolla, CA 92093.

R.L. Tyce, Graduate School of Oceanography, Kingston, RI 028821197

(Received July 10, 1986.

revised May 22, 1987;

accepted July 23, 1987.) 